\title{
BIOLOGICAL CONTROL OF IMPORTANT FUNGAL DISEASES OF POTATO AND RASPBERRY BY TWO BACILLUS VELEZENSIS STRAINS
}

\author{
Anzhela Asaturova ${ }^{\text {Corresp., } 1}$, Margarita Shternshis ${ }^{1}$, Vera Tsvetkova ${ }^{1,2}$, Tatyana Shpatova ${ }^{1,2}$, Vladislava Maslennikova \\ ${ }^{2}$, Natalya Zhevnova ${ }^{1}$, Anna Homyak ${ }^{1}$ \\ ${ }^{1}$ Federal Research Center for Biological Plant Protection, Krasnodar, Krasnodar region, Russian Federation \\ 2 Novosibirsk State Agrarian University, Novosibirsk, Russian Federation \\ Corresponding Author: Anzhela Asaturova \\ Email address: asaturovaanzhela@yandex.ru
}

Stem canker and black scurf caused by Rhizoctonia solani are the important diseases in potato, while spur blight caused by Didymella applanata is a major disease in red raspberry. In Western Siberia, both crops are grown predominantly in small-scale farming that requires maximal usage of biological products for plant protection instead of chemicals. We evaluated two promising Bacillus velezensis strains BZR 336g and BZR 517 isolated in the south of Russia $\left(45^{\circ} 1{ }^{\prime} \mathrm{N}, 38^{\circ} 59^{\prime} \mathrm{E}\right)$ for their biological control potentials against the potato and red raspberry diseases under the more severe weather conditions of Western Siberia $\left(55^{\circ} 1^{\prime} \mathrm{N}, 82^{\circ} 55^{\prime} \mathrm{E}\right)$. We tested two techniques to apply biocontrol agents: (1) coating the seeds (potato tubers) and (2) spraying over the plants (raspberry canes). In each case, we estimated $B$. velezensis strains on two plant cultivars differed by the disease resistance. The degree of $B$. velezensis influence on disease incidence and severity depended on the bacterial strain, the protected plant, and its cultivar. We also demonstrated that two $B$. velezensis strains significantly stimulated plant growth of potato, which contributed to the plant productivity on both cultivars. The BZR 336g strain affected the potato productivity more than the BZR 517 strain. Under the influence of both bacterial strains, raspberry yield was significantly higher compared to the control on the susceptible cultivar. These findings indicated that two southern $B$. velezensis strains had proved their efficacy as biological control agents in the control of the serious fungal infection of potato and raspberry plants under the more severe ecological conditions of Western Siberia. For the first time, we demonstrated $B$. velezensis strains potential for use as biological control agents against $R$. solani on potato, and against $D$. applanata on red raspberry. 
1 Biological control of important potato and raspberry fungal diseases by two

2 Bacillus velezensis strains

Anzhela M. Asaturova ${ }^{1}$, Margarita V. Shternshis ${ }^{1}$, Vera P. Tsvetkova ${ }^{1,2}$, Tatyana V. Shpatova ${ }^{1,2}$, Vladislava S. Maslennikova ${ }^{2}$, Natalya A. Zhevnova ${ }^{1}$ and Anna I. Homyak ${ }^{1}$

${ }^{1}$ Federal Research Center for Biological Plant Protection, Krasnodar, Russian Federation

${ }^{2}$ Novosibirsk State Agrarian University, Novosibirsk, Russian Federation

*Corresponding Author

Anzhela M. Asaturova

Federal Research Center for Biological Plant Protection

Email address: asaturovaanzhela@yandex.ru 


\section{ABSTRACT}

Stem canker and black scurf caused by Rhizoctonia solani are prominent potato diseases, and spur blight caused by Didymella applanata is a disease affecting red raspberry plants. In Western Siberia, both crops are grown predominantly in small-scale farming that requires biological products for plant protection instead of chemicals. We evaluated two promising Bacillus velezensis strains, BZR 336g and BZR 517, isolated in southern Russia $\left(45^{\circ} 1^{\prime} \mathrm{N}, 38^{\circ} 59^{\prime} \mathrm{E}\right)$. As potential biological control agents against potato and red raspberry diseases under severe weather techniques for applying the biocontrol agents: (1) coating the seeds (potato tubers) and (2) spraying the plants (raspberry canes). In each case, we estimated the $B$. velezensis strains on two plant cultivars differed by their disease resistance. The degree of influence that B. velezensis had on disease incidence and severity depended on the bacterial strain, the protected plant, and its cultivar. We also demonstrated that two $B$. velezensis strains significantly stimulated the growth of potato plants, which contributed to plant productivity for both cultivars. The BZR 336g strain affected potato productivity more than the BZR 517 strain did. Raspberry yield was significantly higher under the influence of both bacterial strains compared to the control on the susceptible cultivar. These findings showed that two southern B. velezensis strains were effective biological control agents for the serious fungal infection of potato and raspberry plants under the more severe ecological conditions of Western Siberia. We demonstrated that B. velezensis strains can be used as biological control agents against $R$. solani on potato plants and against $D$. applanata on red raspberry plants.

\section{INTRODUCTION}

Public concern over the harmful effects of chemical fungicides on the environment and human health has emphasized the need for alternative, ecologically-safe methods for controlling plant disease. Current trends in sustainable agriculture are concerned with reducing the use of chemical pesticides that negatively affect the soil and water environment, the quality of agricultural 
46 products, and, as a consequence, animal and human health. An alternative to chemical products is

the use of microbial agents isolated from natural habitats for plant disease control (Lugtenberg, 2018). This is especially important for regions with a short growing season, such as Western Siberia, where it is impossible to fully eliminate the negative effects of chemicals. This region has a severe continental climate characterized by sharp changes in temperature and humidity throughout the year. There are few studies on plant disease biocontrol in the region. Existing research is typically related to the biocontrol agents' efficacy on potato (Solanum tuberosum L.) and berry crops, particularly, red raspberry (Rubus idaeus L.) (Shternshis et al., 2006; Bakhvalov et al., 2015; Tsvetkova et al., 2016). We studied these crops because potato is one of the most common food crops in Western Siberia for its resistance to unpredictable changes of weather. The red raspberry is also sufficiently resistant to unfavorable abiotic environmental factors, especially low temperatures, making it a good candidate for study. This berry crop can withstand temperatures of $-30^{\circ} \mathrm{C}$ and lower (Nestby \&Takeda, 2015; Bogomolova \& Ozherelieva, 2016; Graham \& Brennan, 2018) making its cultivation especially important in areas with a severe climate and sudden temperature changes. Both potato and raspberry are rich in vitamins, microelements, and other biologically active compounds that are beneficial to human health (Rao \& Snyder, 2010; Furrer, Chegeni \& Ferruzzi, 2018). Potato and red raspberry plants are predominantly cultivated on small-scale farms in Western Siberia focused on organic agriculture. This farming method requires the maximal usage of biological products instead of chemicals.

Potato productivity is reduced in different regions of the world due to crop damage by harmful microorganisms. Rhizoctonia solani Kuhn is the most destructive potato disease, causing stem canker and black scurf (Woodhall et al., 2007; Daami-Remadi, Zammouri \& Mahjoub, 2008; Das et al., 2014; Yang et al., 2017). In Western Siberia, the damage caused to potatoes by Rhizoctonia disease can reach 67-70.8\% (Tomilova et al., 2020). One of the most common raspberry fungal diseases is spur blight caused by Didymella applanata (Niessl) Sacc. (Williamson \& Hargreaves, 1981; Stevic, Pavlovic \& Tanovic, 2017; Vojinović et al., 2019). In Western Siberia, spur blight is the most serious red raspberry disease.

Biological controls meet the goals of organic farming (Lynch, Halberg \& Bhatta, 2012). Bacterial action by species from the Bacillus genus, primarily Bacillus subtilis, have effectively controlled a common potato disease caused by $R$. solani in a number of countries for a decade (Kumar et al., 2013; Ben et al., 2015; Dinu, Boiu-Sicuia \& Constantinescu, 2019). In Western 
Siberia, early-maturing potato cultivars are in high demand due to its short vegetative period. However, these plants are more susceptible to yield losses caused by $R$. solani than others in other maturity groups (to an average of $35 \%$ ). Therefore, it requires biological protection since potatoes are produced predominantly by small scale farmers in Western Siberia.

Biological control of red raspberry disease caused by D. applanata has not been wellstudied (Shternshis et al., 2006; Rekanovic et al., 2012). The use of biocontrol agents against plant pathogens has several advantages including increased antifungal activity, stimulating plant growth, and mitigating abiotic stress (Yang, Kloepper \& Ryu, 2009; Maksimov et al., 2015; Jochum et al., 2019) leading to improved plant health (Van Loon, 2007; Pérez-García, Romero \& Vicente, 2011).

Studying beneficial microorganisms to create new biological formulations for plant protection is typically conducted under the same ecological and geographical conditions in which the microorganisms were isolated. These circumstances explain why the application of biological formulations in other climatic regions is not always successful. Thus, it is important to determine biocontrol agents' efficacy in geographically distant regions with different climatic conditions when assessing new strains (Elad \& Pertot, 2014). We studied two perspective Bacillus velezensis strains, BZR 336g and BZR 517 (Garkovenko et al., 2020; Radchenko et al., 2020); both were previously referred to as Bacillus subtilis (Asaturova et al., 2015). These strains were isolated in southern Russia under different environmental conditions. The climate in southern Russia is temperate, suggesting that it has a dry subtropical climate. The lowest temperature reaches $0.8^{\circ} \mathrm{C}$ in January and the highest temperature $\left(35^{\circ} \mathrm{C}\right)$ is reached in July. Snow cover on the soil surface lasts 10-14 days at a height of 10-20 cm. The soils are leached chernozem. The climate of Western Siberia is characterized by long, cold winters and short summers. The lowest temperature reaches $-50{ }^{\circ} \mathrm{C}$ in January and the highest temperature $\left(38^{\circ} \mathrm{C}\right)$ is reached in July. The snow cover on the soil surface lasts 148-170 days at a height of more than $50 \mathrm{~cm}$. The maximum soil freezing depth is $257 \mathrm{~cm}$. The soils are gray forest.

$B$. velezensis strains are known as biological control agents that suppress certain dangerous plant diseases caused by $R$. solanacearum on tomato (Chen et al., 2020), Fusarium graminearum on corn (Wang et al., 2020), and Botrytis cinerea on strawberry (Toral et al., 2020). In addition to biocontrol, B. velezensis strains may promote plant growth (Fan et al., 2018; Myo et al., 2019; Torres et al., 2020). To date, there is no research on B. velezensis' biocontrol of $R$. solani on potato or D. applanata on raspberry diseases. In this study, we examined the effect of B. velezensis 
BZR $336 \mathrm{~g}$ and $B$. velezensis BZR 517 strains isolated in southern Russia on suppressing Rhizoctonia disease on potato and spur blight on red raspberry in Western Siberia, which is a geographically distant region with much more severe climate conditions.

\section{MATERIALS \& METHODS}

\section{Bacillus strains used for experiments}

The B. velezensis BZR 336g (Assembly: GCA_009683125.1, GenBank: NZ_WKKU00000000.1) and B. velezensis BZR 517 (Assembly: GCA_009683155.1, GenBank: NZ_WKKV00000000.1) strains were originally isolated from the winter wheat rhizosphere in the Krasnodar region $\left(45^{\circ} 1\right.$ ' $\mathrm{N}$, 38 $\left.{ }^{\circ} 9^{\prime} \mathrm{E}\right)$. The strains belonged to the Federal Research Center for Biological Plant Protection's (Russia) "State Collection of Entomoacariphages and Microorganisms" bioresource collection (No. 585858). The material and technical facilities of the unique scientific installation «New generation technological line for developing microbiological plant protection products» of the Federal Research Center for Biological Plant Protection's (Russia) were used in the research (http://ckp-rf.ru/ registered No 671367).

The strains were stored at $4{ }^{\circ} \mathrm{C}$ in test tubes with potato-glucose agar $(50 \%$ potato broth, $2 \%$ glucose, $2 \%$ agar). For each experiment, fresh liquid cultures were prepared on the original optimized nutrient medium in New Brunswick Scientific Excella E25 (USA) incubator shakers (180 rpm). The optimized culture medium was created using Czapek's medium for bacteria. Molasses was used as a carbon source and corn extract was used as a nitrogen source (Asaturova et al., 2015). The B. velezensis BZR 336g culture was cultivated at $25^{\circ} \mathrm{C}$ for 48 hours, and the $B$. velezensis BZR 517 culture was cultivated at $30{ }^{\circ} \mathrm{C}$ for 36 hours. These parameters were obtained from a previous study (Sidorova et al., 2020).

\section{In vitro antifungal activity of Bacillus strains}

We evaluated the antagonistic properties of $B$. velezensis strains against the phytopathogenic fungus $R$. solani, isolated from infected potato tubers, and against fungus $D$. applanata, isolated from infected raspberry canes in Western Siberia. B. velezensis BZR 336g and B. velezensis BZR 517 strains were used at concentrations of $10^{4}-10^{6} \mathrm{CFU} / \mathrm{mL}$. The experiment was conducted using the agar block techniques (Shternshis et al., 2016). 
138

139

140

141

142

143

144

145

146

147

148

149

150

151

152

153

154

155

156

157

158

159

160

161

162

163

164

165

166

167

Strains' liquid cultures were introduced into potato glucose agar and Czapek medium for $R$. solani and D. applanata, respectively, at the indicated concentrations and poured into sterile petri dishes.

The solution was allowed to solidify before a $10 \mathrm{~mm}$ diameter agar block with a phytopathogenic fungus was placed in the center of the dish. The plates were incubated at $25^{\circ} \mathrm{C}$ for 14 days in darkness. Petri dishes with a medium served as the control. Experiments were replicated five times and the entire experiment was conducted twice.

Antagonistic activity was evaluated by measuring the diameter of the fungal colonies after 3,5 , and 7 days. The fungal inhibition (I, \%) was determined based on the data obtained:

$\mathrm{I}, \%=(\mathrm{Dc}-\mathrm{Dt}) / \mathrm{Dc} \times 100$, where $\mathrm{Dc}$ is the diameter of fungal colony in control and $\mathrm{Dt}$ is the diameter of fungal colony in treatment.

\section{Weather conditions in the summer months of 2015 and 2016}

The average summer temperature in 2015 was $18.6{ }^{\circ} \mathrm{C}$ and $19.1{ }^{\circ} \mathrm{C}$ in 2016 . The amount of precipitation for the same period in 2015 was $207 \mathrm{~mm}$ and $135 \mathrm{~mm}$ in 2016. The lowest precipitation occurred in June in 2015, and June and August in 2016. The wettest month was July in 2015. Higher temperatures were noted in July 2016 compared to July 2015.

\section{Field trials of $B$. velezensis strains on potato plants}

Field trials were conducted on experimental plots at the Novosibirsk State Agrarian University $\left(55^{\circ} 1^{\prime} \mathrm{N}, 82^{\circ} 55^{\prime} \mathrm{E}\right)$. Plant growth conditions included weeding, inter-row cultivation, and hilling. We used Kemira potato complex fertilizer (Fertika, Russia) (50 g per m2) consisting of nitrogen (11\%), phosphorus (9\%), potassium (17\%), magnesium (2.7\%), and sulfur (2.7\%). We cultivated two potatoes from different maturity groups: early maturity cv. Yuna and mid-early cv. Svitanok kievskiy.

Each plot measured $30 \mathrm{~m}^{2}$ and included 120 plants. Potato seed tubers were dipped for 30

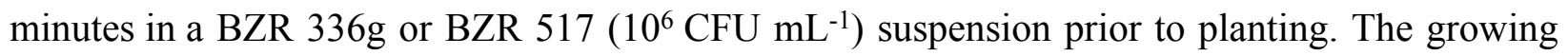
season was 3 months, during which the potato plant height, the number of above-ground stems, the biomass of daughter tubers, and potato yield were measured at 4, 6 , and 10 weeks after planting. The experiment was arranged using a completely randomized block design. Four plot areas (10 
$168 \mathrm{~m}^{2}, 40$ plants per plot) were subjected to each treatment. Tubers treated with water were used as 169 control. Two independent experiments were performed. We did not observe any diseases except R. solani.

We assessed potato stems infected by $R$. solani and the plants' morphometric characteristics (height and number of stems per plant) 4, 6, and 10 weeks after planting. The disease incidence (DI \%) was calculated by the formula: DI $(\%)=(\mathrm{Tx} 100) / \mathrm{N}$, where $\mathrm{T}$ is the number of infected plants and $\mathrm{N}$ is the total number of plants. Disease severity (DS, \%) was estimated using the Townsend-Heuberger formula according to the following scale: $0=$ no disease symptoms; $1=$ stem canker up to $25 \mathrm{~mm} ; 2=$ stem canker up to $50 \mathrm{~mm} ; 3=$ stem canker more than $50 \mathrm{~mm} ; 4$ = canker surround the whole stem; 5 = stem completely nipped (Frank, Leach \& Webb, 1976).

For daughter tubers the disease incidence (DI, \%) was calculated using the formula:

DI $(\%)=(\mathrm{Tx} 100) / \mathrm{N}$, where $\mathrm{T}$ was the number of infected daughter tubers and $\mathrm{N}$ was the total number of daughter tubers.

We determined tubers' biomass distribution by their weight. The daughter tubers were categorized as: small (less than $35 \mathrm{~g}$ ), medium (36-180 g), or large (more than $180 \mathrm{~g}$ ). Yields were determined by weighing all daughter tubers from each plot.

\section{Field trials of Bacillus strains on raspberry plants}

Raspberry plants were also represented by two cultivars: cv. Kirzhach is non-resistant to Didymella applanata and cv. Kolokolchik is resistant to this fungal pathogen. The raspberry cultivar Kolokolchik was selected at the Siberian Research Institute of Horticulture (Barnaul, Russia), and the raspberry cultivar Kirzhach was selected from the All-Russian Institute of Horticulture and Nursery (Moscow, Russia). Raspberry plots were located at the Siberian Research Institute of Crop Production and Breeding's experimental station. Plant growth conditions included weeding and inter-row cultivation until the raspberry flowering stage. In these experiments, plots were not fertilized. During our study, we did not observe raspberry diseases other than D. applanata.

Plants were located in rows $40 \mathrm{~cm}$ wide; rows were spaced $2.5 \mathrm{~m}$ apart. The area of each plot was $10 \mathrm{~m}^{2}$ and included 50 raspberry canes in four replicates. The size of the buffer zone between plots was $2 \mathrm{~m}$. B. velezensis BZR 336g and B. velezensis 517 strains were suspended at a concentration of $10^{6} \mathrm{CFU} \mathrm{mL} \mathrm{mL}^{-1}$ and used to manage raspberry disease. B. velezensis suspensions 
199 were applied at a volume application rate of $0.1 \mathrm{~L} / \mathrm{m}^{2}$ using a hand-held Orion-6 sprayer (Quazar 200 Corp. Warsaw, Poland). The control plots were treated with water. Two independent experiments were performed. Bacterial strain treatment timing was determined at the appearance of the first disease symptoms. Observations were carried out throughout the growing season for 2 years.

Disease severity (DS, \%) was estimated using the Townsend-Heuberger formula according to the following scale: $0=$ healthy cane; $1=$ patches with a smooth surface and a diameter less than 0.5 of the cane girth, appearance of splits was possible; $2=$ patches with a smooth surface and the diameter more than 0.5 of the cane girth, appearance of splits was possible; 3 = patches with a deformed surface and the diameter more than 0.5 of the cane girth, splits or tissue deformation that come up to the vascular cylinder; $4=$ patches with a deformed surface that completely cover the whole cane girth, splits or tissue deformation that come up to vascular cylinder (Shternshis et al., 2002). The disease incidence (DI, \%) was calculated using the same formula used for potato plants.

A randomized complete block design was used to assign treatments to four replicates for both potato and raspberry cultures. We manually harvested the crops and the yields were determined by weighing all potato daughter tubers or all harvested raspberry fruits from each plot.

\section{Statistical analysis}

We processed our data using Excel 2010 (Microsoft Corporation). All results are expressed as the mean. We used STATISTICA 13.2 EN (trial version, Tibco, USA) to statistically analyze the data. Multiple comparisons of the means were performed using Duncan's tests with a significance level of $\mathrm{P}=0.05$.

\section{RESULTS}

\section{Screening B. velezensis against $R$. solani and $D$. applanata in vitro}

The studied strains inhibited the growth of $R$. solani and D.applanata under laboratory conditions (Fig. 1). The inhibition ratio depended on the concentration of bacteria in the nutrient medium (Tables 1 and 2). The progressive reduction of fungal growth was noted with increasing suspension concentration of $B$. velezensis strains. After 7 days, the diameter of the $R$. solani colonies under the action of two strains of $B$. velezensis significantly decreased at least five times $(\mathrm{P}<0.05)$, and 
the percentage of the bacterial strains' inhibition activity at concentrations of $10^{5}$ and $10^{6} \mathrm{CFU} / \mathrm{mL}$ was rather high (Table 1). The same tendency was observed for D. applanata $(\mathrm{P}>0.05)$ although the inhibitory effect was not as evident (Fig. 1; Table 2). In both cases, the inhibitory effect increased with time (Tables 1 and 2).

\section{Potato field trials}

The disease incidence on potato stems in the control permanently increased during the growing seasons of in 2015 and 2016. The disease incidence in both years was no less than $80 \%$ on two potato cultivars in the control group 10 weeks after planting (Table 3). Using B. velezensis strains for 2 years reduced the disease incidence and severity on potato stems, the degree of which depended on the strain, potato cultivar, and weather conditions that year. In 2015, a statistically significant decrease of the disease incidence $(\mathrm{P}<0.05)$ was observed in both potato cultivars in all cases 6 weeks after planting (Table 3). The disease severity on the stems decreased by $79.8 \%$ under BZR 336g ( $\mathrm{P}<0.05)$, and by $23.1 \%$ under BZR 517 (P>0.05) on cv. Svitanok kievskiy, and cv. Yuna by $69.5 \%$ and $50 \%$, respectively $(\mathrm{P}<0.05)$ (Table 3$)$. During the same period in 2016, a statistically significant decrease in disease severity of $74.1 \%$ was observed on cv. Yuna, under the action of the BZR 336g strain and of $50 \%$ by BZR $517(\mathrm{P}<0.05)$ (Table 3).

The greatest decrease in the disease' incidence and severity on the stems after application was achieved 10 weeks after treatment by bacilli in both 2015 and 2016. In 2015, 10 weeks after treating Svitanok kievskiy tubers with the B. velezensis BZR 336g strain, the disease incidence decreased by $71.5 \%$, and on cv. Yuna by $61.1 \%(\mathrm{P}<0.05)$. In the same year, the strains' influenced on disease severity was even stronger $(\mathrm{P}<0.05)$ (Table 3 ), and a smaller effect was observed on cv. Yuna. In 2016, with less air humidity, bacilli's effect on the disease incidence and severity was statistically smaller $(\mathrm{P}<0.05)$ than in the previous year (Table 3$)$.

The stem damage during the growing season in the control group resulted in a large number of daughter tubers infected by $R$. solani sclerotia. Damage was especially prominent in 2016, when the disease incidence in the control daughter tubers was $86.7 \%$ (Table 3). However, treating tubers with $B$. velezensis strains significantly reduced the disease incidence in daughter tubers. This value decreased by $71.5 \%$ in 2015 and by $93.5 \%$ in 2016 in cv. Svitanok kievskiy when using the BZR 336g strain (Table 3). The BZR 517 strain decreased the disease incidence by $49.6 \%$ and $89.6 \%$, respectively $(\mathrm{P}<0.05)$. In $\mathrm{cv}$. Yuna daughter tubers, the data for both strains differed from the 
control significantly in both years. In 2015, the strain BZR 517 was 3.3 times more effective compared to BZR 336g. In 2016, BZR 517 was significantly less effective than BZR 336g (P < 0.05) (Table 3).

The bacterial strains also contributed to the potato plant growth stimulation during the growing seasons. In 2015, the seed treatment led to significant increase in plant height $(\mathrm{P}<0.05)$ in the most cases (Table 4). Under the influence of both strains, in cv. Svitanok kievskiy the number of stems per plant significantly increased in 4, 6, and 10 weeks after planting. A similar result was observed in $\mathrm{cv}$. Yuna $(\mathrm{P}<0.05)$ (Table 4). The effect of these strains on plant height in 2016 was less for cv. Svitanok kievskiy (Table 4). Ten weeks after planting, treating the two potato cultivars with both strains over 2 years led to a significant increase in the morphometric characteristics of the plants (Table 4).

The pre-planting treatment of potato tubers with the bacterial strains had a positive effect on the quality of the daughter tubers. Thus, the effect of the strain BZR 336g appeared to increase with the increasing biomass of the tubers. In 2015, the effect was increased by $37.2 \%$ and by 45.0 $\%$ in cv. Svitanok kievskiy and cv. Yuna, respectively (Table 5). In 2016, the biomass was increased by 31.3-38.0\% in both cultivars (Table 5). BZR 517 caused an increase in the medium fraction of tubers (Table 5). As a result, the use of the BZR 336g strain provided a significant increase of $41.4 \%$ in daughter tubers' biomass in the mid-early cv. Svitanok kievskiy in 2015. In 2016, biomass increased by $62.9 \%$. The biomass was increased in early cv. Yuna by $22.4 \%$ and by $27.4 \%(\mathrm{P}<0.05)$, respectively (Table 5). Tubers pre-treated with the BZR 517 strain contributed less to the yield formation. In 2015, the daughter tubers's biomass increased by $10 \%$ (cv. Svitanok kievskiy) and by $17.1 \%$ (cv. Yuna), respectively (Table 5). In 2016, the tuber biomass increased by $42.2 \%$ (cv. Svitanok kievskiy) and by $26.5 \%$ (cv. Yuna) compared with the control $(\mathrm{P}<0.05)($ Table 5$)$. The total potato yield was significantly increased in both cultivars compared to the control $(\mathrm{P}<0.05)$ (Table 5).

\section{Red raspberry field trials}

Raspberry cane disease incidence increased in the control differently during the 2 year study period. This increase was more serious during the 2015 season than in 2016 (Table 6) due to increased precipitation in 2015 (207 $\mathrm{mm})$ compared to $2016(135 \mathrm{~mm})$. 
B. velezensis strains were able to reduce the disease incidence. In 2015, we observed a 69.3 $\%(\mathrm{P}<0.05)$ reduction in disease incidence 4 weeks after BZR 517 treatment on cv. Kirzhach; in cv. Kolokolchik, the reduction was $50.0 \%$ ( $\mathrm{P}>0.05)$. In 12 weeks, B. velezensis significantly $(\mathrm{P}<0.05)$ reduced this value by $46.4 \%$ in cv. Kirzhach, and by $59.7 \%$ in cv. Kolokolchik (Table 6). In 2016, 4 and 12 weeks after the treatment both strains significantly reduced disease incidence $(\mathrm{P}<0.05)$ to the same degree in cv. Kirzhach (Table 6). The disease incidence was reduced by more 
Certain Bacillus strains have been shown to effectively control $R$. solani disease on potato in different geographic regions around the world (Saber et al., 2015; Dinu et al., 2019; Larkin, 2020). However, no studies have been conducted using B. velezensis for this purpose.

We revealed the ability of the studied strains to suppress Rhizoctonia disease for two potato cultivars (early maturity cv. Yuna and mid-early maturity cv. Svitanok kievskiy) in Western Siberia using field trials for 2 years. The conditions differed in terms of temperature and environmental humidity. We showed the ability of $B$. velezensis strains isolated in the warm region south of Russia to remain active against $R$. solani in the more severe climactic conditions of Western Siberia. The Bacillus species are known to inhibit the growth of $R$. solani by producing lipopeptides, chitinases, surfactins and other biologically active metabolites (Saber et al., 2015; Shafi et al., 2017). In addition, some authors have demonstrated the ability of $B$. velezensis strains to stimulate plant growth (Ye et al., 2018; Dinu et al., 2019; Myo et al., 2019). The results of our two-year research showed that, along with the antifungal effect, the bacilli stimulated plant growth by increasing parameters such as plant height and number of stems per plant. In addition, data presented in our study are in accordance with other research indicating that some Bacillus strains offer additional benefit to the plants, such as increased tolerance to abiotic stress and growth promotion (Enebe \& Babalola, 2018; Shameer \& Prasad, 2018; Jochum et al., 2019). Our results also correspond to other research on two Bacillus strains that protected potato plants against abiotic stress (Vurukonda et al., 2016).

We indicated that the two B. velezensis strains' efficacy against $R$. solani was dependent on the potato cultivar. According to the several parameters, such as disease incidence and severity on the potato stems and daughter tubers, plant growth stimulation, and daughter tubers' biomass, the response of potato plants of mid-early maturity cv. Svitanok kievskiy to the bacilli treatment was more pronounced compared with the early maturity $\mathrm{cv}$. Yuna. It should be noted that we used two $B$. velezensis strains at a concentration of $10^{6} \mathrm{CFU} \mathrm{mL} \mathrm{mL}^{-1}$ to control $R$. solani which were less than typically used in research.

A positive effect of the studied $B$. velezensis strains resulted in increased potato crop productivity. Decreased potato yield in 2016 compared to 2015 should be explained by the drought during the period of active tuberization. June and early July 2016 were dry, and only $165.7 \mathrm{~mm}$ of rainfall was observed during the vegetation period, which is 1.7 times less than long-term annual 
data. However, it was excessively wet in July 2015. In general, the strain BZR 336g contributed more significantly to the tuber yield.

We also compared the effectiveness of these two B. velezensis strains on red raspberry plants that differed by plant biology and other biological features. The results of field testing two bacterial strains on red raspberry plants revealed their effectiveness against spur blight depended both on the properties of the bacterial strain and on the raspberry cultivar. In 2015 and 2016, the increase in disease incidence and severity on raspberry canes was also demonstrated during the growing season in control. We observed some distinction between the two cultures in addition to the similar tendency in the influence of bacterial strains on two different plants. The disease suppression was significantly more pronounced under B. velezensis BZR $336 \mathrm{~g}$ in potatoes. However, B. velezensis BZR 517 and B. velezensis BZR 336g performed almost similarly against raspberry spur blight. The raspberry yield slightly increased after bacilli treatment on cv. Kirzhach but this was not reflected in the resistant cv. Kolokolchic.

It is also well known that modes of action of biocontrol agents include induced systemic resistance (ISR). Direct antifungal effect, plant growth promotion, and enhanced tolerance to abiotic stress may be due to the mechanism of ISR (Kloepper et al., 2004; Van Loon, 2007; Pieterse et al., 2014; Kohl et al., 2019). ISR often aids B. velezensis in protecting against phytopathogens (Chen et al., 2018; Grady et al., 2019; Rabbee et al., 2019; Xie et al., 2019). ISR initiation requires beneficial microbes to efficiently colonize the root systems of host plants. This was confirmed by applying Bacillus strains to various plants (Pieterse et al., 2014). However, there is less research showing ISR's possible contributions to the treatment of plants' above grounds parts. Thus, we should assume that B. velezensis's contributions to the ISR mechanism in potato may be greater than in raspberry, which was confirmed by their influence on crop yields.

According to our data, the $B$. velezensis strains isolated in a favorable agroecological environment demonstrated that they are effective under more severe ecological and geographical conditions and can managing potato and raspberry plant health in Western Siberia. This was dependent on the bacterial strain, the protected plant, the plant cultivar, and on the pathogen causing the plant disease.

We also demonstrated that two B. velezensis strains stimulated the growth of the potato plant, which contributed to the plant productivity. It should be noted that biocontrol methods are very promising sources of plant disease control in organic farming (Lindsey, Murugau \& Rentita, 
382 2020). Some $B$. velezensis strains are used in organic agriculture as an alternative to chemical 383 pesticides (Charon-Lamoureux et al., 2020). Organic farming systems are more profitable and environmentally friendly; they deliver foods that contain less (or no) pesticide residues when compared with conventional farming (Reganold \& Wachter, 2016). This is important for potato and raspberry planted in small farms. According to Jouzi et al. (2017), organic farming may present some significant challenges to small-scale farmers.

\section{CONCLUSIONS}

We showed that two southern $B$. velezensis strains were effective as biological control agents in the control of the serious fungal infection of potato and raspberry plants in the field under the more severe ecological conditions than those from which they were isolated. Overall, the use of two $B$. velezensis strains on potato and red raspberry cultivars under conditions of Western Siberia improved plant health and may protect the environment. The strains studied are the basis for developing new biocontrol formulations suitable for applications in geographic locations with highly different environmental conditions. Their use corresponds with the aims of sustainable agriculture. The use of biocontrol agents as an alternative to chemical fungicides is in line with the goals of sustainable horticulture. We demonstrated the novel potential use of $B$. velezensis strains as biological control agents against $R$. solani on potato plants and against $D$. applanata on red raspberry plants.

\section{REFERENCES}

Asaturova AM, Homyak AI, Tomashevich NS, Pavlova MD, Zhevnova NA, Dubyaga VM, Kozitsyn AE, Sidorova TM, Nadykta VD, Ismailov VYa. 2015. Conditions for the cultivation of new Bacillus bacteria being micro bioproduct producers. Journal of Pure and Applied Microbiology 9(4): 2797-2804.

Bakhvalov SA, Tsvetkova VP, Shpatova TV, Shternshis MV, Grishechkina SD. 2015. Ecological interaction in the system: entomopathogenic bacteria Bacillus thuringiensis phytopathogenic fungus Rhizoctonia solani - host plant Solanum tuberosus. Contemporary Problems of Ecology 8 (4): 534-539. DOI 10.1134/S1995425515040034 
Ben Khedher S, Kilani-Feki O, Dammaka M, Jabnoun-Khiareddine H, Daami-Remadi M, Tounsi S. 2015. Efficacy of Bacillus subtilis V26 as a biological control agent against Rhizoctonia solani on potato. Comptes Rendus Biologies 338:784-792. DOI 10.1016/j.crvi.2015.09.005

Bogomolova NI, Ozherelieva ZE. 2016. An adaption potential of red raspberry to damaging winter factors in the field and controlled conditions of central Russia. Contemporary Horticulture 4: 41-52.

Charon-Lamoureux V, Thérien M, Konk A, Beauregard PB. 2020. Bacillus subtilis and Bacillus velezensis population dynamic and quantification of spores after inoculation on ornamental plants. Canadian Journal of Microbiology. DOI 10.1139/cjm-2020-0174

Chen L, Heng J, Qin S, Bian K. 2018. A comprehensive understanding of the biocontrol potential of Bacillus velezensis LM2303 against Fusarium head blight. PLoS ONE 13(6): e0198560. DOI 10.1371/journal.pone.0198560

Chen M, Wang J, Liu B, Zhu Y, Xiao R, Yang W, Ge1 C, Chen Z. 2020. Biocontrol of tomato bacterial wilt by the new strain Bacillus velezensis FJAT-46737 and its lipopeptides. BMC Microbiology 20:160. DOI:10.1186/s12866-020-01851-2

Daami-Remadi M, Zammouri SE, Mahjoub M. 2008. Effect of the level seed tuber infection by Rhizoctonia solani at planting on potato growth and disease severity. African Journal of Plant Science and Biotechnology 2(1): 34-38.

Das S, Shah FA, Butler RC, Falloon RE, Stewart A, Ranker S, Pitman R. 2014. Genetic variability and pathogenicity of Rhizoctonia solani associated with black scurf of potato in New Zealand. Plant Pathology, 63(3):651-666. DOI: 10.1111/ppa.12139

Dinu S, Boiu-Sicuia O-A, Constantinescu F. 2019. Influence of Bacillus spp. based bioproducts on potato plant growth and control of Rhizoctonia solani. Bulletin UASVM Animal Science and Biotechnologies 76(1):29-34. DOI:10.15835/buasvmcn-asb: 2018-0022

Elad Y, Pertot I. 2014. Climate change impacts on plant pathogens and plant diseases. Journal of Crop Improvement 28:99-139. DOI: 10.1080/15427528.2014.865412

Enebe MC, Babalola OO. 2018. The influence of plant growth-promoting rhizobacteria in plant tolerance to abiotic stress: a survival strategy. Applied Microbiology and Biotechnology 102: 7821-7835. DOI: 10.1007/s00253-018-9214-z 
Frank JA, Leach SS, Webb RA. 1976. Evaluation of potato clone reaction to Rhizoctonia solani. Plant Disease Reporter 60(11): 910-912.

Fan B, Wang C, Song X, Ding X, Wu L, Wu H, Gao X, Borriss R. 2018. Bacillus velezensis FZB42 in 2018: The Gram-Positive Model Strain for Plant Growth Promotion and Biocontrol. Frontiers in Microbiology 9:2491. DOI: 10.3389/fmicb.2018.02491

Furrer AN, Chegeni M, Ferruzzi MG. 2018. Impact of potato processing on nutrients, phytochemicals and human health. Critical Reviews in Food Science and Nutrition 58(1): 146-68. DOI: 10.1080/10408398.2016.1139522

Garkovenko AV, Vasilyev IY, Ilnitskaya EV, Radchenko VV, Asaturova AM, Kozitsyn AE, Tomashevich NS, Milovanov AV, Grigoreva TV, Shternshis MV. 2020. Draft genome sequence of Bacillus velezensis BZR 336g, a plant growth promoting antifungal biocontrol agent isolated from winter wheat. Microbiology Resource Announcement 9:e00450-20. DOI: 10.1128/MRA .00450-20

Grady EN, MacDonald J, Ho MT, Weselowski B, McDowell T, Solomon O, Renaud J, Yuan Z-C. 2019. Characterization and complete genome analysis of the surfactin-producing, plant-protecting bacterium Bacillus velezensis 9D-6. BMC Microbiology 19:5. DOI:10.1186/s12866-018-1380-8

Graham J, Brennan R. (Eds.) 2018. Raspberry: breeding, challenges and advances. Cham: Springer.

Jochum MD, McWilliams KL, Borrego EJ, Kolomiets MV, Niu G, Pierson EA, Jo Y-K. 2019. Bioprospecting plant growth-promoting rhizobacteria that mitigate drought stress in grasses. Frontiers in Microbiology 10:2106. DOI: 10.3389/fmicb.2019.02106

Jouzi Z, Azadi H, Taheri F, Zarafshani K, Gebrehiwot K, Van Passel S, Lebailly P. 2017. Organic Farming and Small-Scale Farmers: Main Opportunities and Challenges. Ecological Economics 132: 144-154. DOI: 10.1016/j.ecolecon.2016.10.016

Kloepper JW, Ryu C-M, Zhang S. 2004. Induced systemic resistance and promotion of plant growth of Bacillus spp. Phytopathology 94:1259-1266.

DOI: 10.1094/PHYTO.2004.94.11.1259

Kohl J, Kolnaar R, Ravensberg J. 2019. Mode of action of microbial biological control agents against plant diseases: Relevance beyond efficacy. Frontiers in Plant Sciences 10:845. DOI:10.3389/fpls.2019.00845 
Kumar SS, Rao MRK, Kumar RD, Panwar S, Prasad CS. 2013. Biocontrol by plant growth promoting rhizobacteria against black scurf and stem canker disease of potato caused by Rhizoctonia solani. Archives of Phytopathology and Plant Protection 46(4): 487-502. DOI: $10.1080 / 03235408.2012 .745054$

Larkin R. 2020. Biological control of soilborne diseases in organic potato production using hypovirulent strains of Rhizoctonia solani. Biological Agriculture \& Horticulture 36: 119129. DOI: $10.1080 / 01448765.2019 .1706636$

Lindsey APJ, Murugau S, Rentita RE. 2020. Microbial disease management in agriculture: Current status and future prospects. Biocatalysis and Agricultural Biotechnology 23: 101468. DOI: $10.1016 /$ j.bcab.2019.101468

Lugtenberg B. 2018. Putting concerns for caution into perspective: microbial plant protection products are safe to use in agriculture. Journal of Plant Diseases and Protection 125(2):127-129. DOI:10.1007/s41348-018-0149-5

Lynch DH, Halberg N, Gopal D, Bhatta GD. 2012. Environmental impacts of organic agriculture in temperate regions. CAB Reviews 7: 010.

DOI: 10.1079/PAVSNNR20127010

Maksimov IV, Veselova SV, Nuzhnaya TV, Sarvarova ER, Khairullin RM. 2015. Plant growth-promoting bacteria in regulation of plant resistance to stress factors. Russian Journal of Plant Physiology 62: 715-726. DOI:10.1134/S1021443715060114

Myo EM, Liu B, Ma J, Shi L, Jiang M, Zhang K, Ge B. 2019. Evaluation of Bacillus velezensis NKG-2 for bio-control activities against fungal diseases and potential plant growth promotion. Biological Control 134:23-31. DOI: 10.1016/j.biocontrol.2019.03.017

Nestby R, Takeda F. 2015. Method to reduce low temperature stress (LTS) in red raspberry (Rubus idaeus L.). Journal of Berry Research 5: 219-230. DOI:10.3233/JBR-150104

Pérez-García A, Romero D, Vicente A. 2011. Plant protection and growth stimulation by microorganisms: biotechnological application of Bacilli in agriculture. Current Opinion in Biotechnology 22(2): 187-193. DOI: 10.1016/j.copbio.2010.12.003

Pieterse CMJ, Zamioudis C, Berendsen RL, Weller DM, Van Wees SCM, Bakker PAHM. 2014. Induced systemic resistance by beneficial microbes. Annual Review of Phytopathology 52: 347-375. DOI: 10.1146/annurev-phyto-082712-102340 
Rabbee MF, Ali MS, Choi J, Hwang BS, Jeong SC, Baek K. 2019. Bacillus velezensis: A valuable member of bioactive molecules within plant microbiomes. Molecules 24:1046. DOI:10.3390/molecules24061046

Radchenko VV, Vasilyev IY, Ilnitskaya EV, Garkovenko AV, Asaturova AM, Tomashevich NS, Alexander E. Kozitsyn AE, Milovanov AV, Tatiana V. Grigoreva TV, Shternshis MV. 2020. Draft genome sequence of the plant growth promoting bacterium Bacillus subtilis strain BZR 517, isolated from winter wheat, now reclassified as Bacillus velezensis strain BZR 517. Microbiology Resource Announcement 9:e00853-20. DOI: 10.1128/MRA.00853-20.

Rao AV, Snyder DM. 2010. Raspberries and human health: a review. Journal of Agricultural Food and Chemistry 58 (7): 3871-3883. DOI: 10.1021/jf903484g

Reganold JP, Wachter JM. 2016. Organic agriculture in the twenty-first century. Nature Plants 2: 1-8.| DOI: 10.1038/NPLANTS.2015.221

Rekanovic E, Stepanovic M, Potocnik I, Milijasevic-Marcic S, Todorovic B, Duduk B, Gavrilovic V. 2012. Field efficacy of fungicides and biofungicides in the control of spur blight of raspberries in Serbia. Acta Horticulturae 946:289-292. DOI: 10.17660/ActaHortic.2012.946.47

Saber WIA, Ghoneem KM, Al-Askar AA, Younes M, Rashad YM, Ali AA, Rashad EM. 2015. Chitinase production by Bacillus subtilis ATCC 11774 and its effect on biocontrol of Rhizoctonia diseases of potato. Acta Biologica Hungarica 66(4):436-448. DOI: $10.1556 / 018.66 .2015 .4 .8$

Shafi J, Tian H, Ji M. 2017. Bacillus species as versatile weapons for plant pathogens: a review. Biotechnology \& Biotechnological Equipment 31(3):446-459. DOI: $10.1080 / 13102818.2017 .1286950$

Shameer S, Prasad TNVV. 2018. Plant growth promoting rhizobacteria for sustainable agricultural practices with special reference to biotic and abiotic stresses. Plant Growth Regulation 84: 603-615. DOI: 10.1007/s10725-017-0365-1

Shternshis MV, Beljaev AA, Shpatova TV, Bokova JV, Duzhak AB. 2002. Field testing of BACTICIDE $^{\circledR}$, PHYTOVERM $^{\circledR}$ and CHITINASE for control of the raspberry midge blight in Siberia. BioControl 47: 697-706. DOI: 10.1023/A:1020574914831 
Shternshis MV, Beljaev AA, Shpatova TV, Duzhak AB, Panfilova ZI. 2006. The effect of chitinase on Didymella applanata, the causal agent of raspberry cane spur blight. BioControl 51: 311-32. DOI: 10.1007/s10526-005-1034-2

Shternshis MV, Shpatova TV, Belyaev AA. 2016. Effect of two biological formulations based on Bacillus subtilis and Pseudomonas fluorescens on control of Didymella applanata, the causal agent of red raspberry cane spur blight. International Journal of Agronomy. Article ID 2797125:6 pp. DOI:10.1155/2016/2797125

Sidorova TM, Asaturova AM, Homyak AI, Zhevnova NA, Shternshis MV, Tomashevich NS. 2020. Optimization of laboratory cultivation conditions for the synthesis of antifungal metabolites by bacillus subtilis strains. Saudi Journal of Biological Sciences 27(7): 1879-1885. DOI: 10.1016 / j.sjbs.2020.05.002

Stevic M, Pavlovic B, Tanovic B. 2017. Efficacy of fungicides with different modes of action in raspberry spur blight (Didymella applanata) control. Pesticide and Phytomedicine (Belgrade) 32(1): 25-32.

Tomilova OG, Shaldyaeva EM, Kryukova NA, Pilipova YV, Schmidt NS, Danilov VP, Kryukov VY, Glupov VV. 2020. Entomopathogenic fungi decrease Rhizoctonia disease in potato in field conditions. PeerJ 8: e9895. DOI:10.7717/peerj.9895

Toral L, Rodríguez M, Béjar V, Sampedro I. 2020. Crop protection against Botrytis cinerea by rhizhosphere biological control agent Bacillus velezensis XT1. Microorganisms 8:992. DOI:10.3390/microorganisms 8070992

Torres M, Llamasa I, Torres B, Toral L, Sampedro I, Béjar V. 2020. Growth promotion on horticultural crops and antifungal activity of Bacillus velezensis XT1. Applied Soil Biology 150: 103453 . DOI: $10.1016 /$ j.apsoil.2019.103453

Tsvetkova VP, Shternshis MV, Shatalova EI, Bakhvalov SA, Maslennikova VS, Grishechkina SD. 2016. Polyfunctional properties of the entomopathogenic bacterium in protecting potato in Western Siberia. Bioscience Biotechnology Research Asia 13(1):9-15. DOI: $10.13005 / \mathrm{bbra} / 1996$

Van Loon LC. 2007. Plant responses to plant growth-promoting rhizobacteria. European Journal of Plant Pathology 119: 243-244. DOI: 10.1007/s10658-007-9165-1

Vojinović U, Pavlović B, Tanović B, Stević M. 2019. Sensitivity and efficacy of the succinate dehydrogenase inhibitor fluxapyroxad, against raspberry spur blight fungus Didymella 
applanata. Journal of Plant Diseases and Protection 126: 145-152. DOI: 10.1007/s41348019-00208-w

Vurukonda SSKP, Vardharajula S, Shrivastava M, Ali SkZ. 2016. Enhancement of drought stress tolerance in crops by plant growth promoting rhizobacteria. Microbiological Research 184: 13-24. DOI: 10.1016/j.micres.2015.12.003

Wang S, Sun L, Zhang W, Chi F, Hao X, Bian J, Li Y. 2020. Bacillus velezensis BM21, a potential and efficient biocontrol agent in control of corn stalk rot caused by Fusarium graminearum. Egyptian Journal of Biological Pest Control 30:9. DOI:10.1186/s41938020-0209-6

Williamson B, Hargreaves AJ. 1981. Effects of Didymella applanata and Botrytis cinerea on axillary buds, lateral shoots and yield of red raspberry. Annals of Applied Biology 97: 5564. DOI: 10.1111/j.1744-7348.1981.tb02994.x

Woodhall JW, Lees AK, Edwards SG, Jenkinson P. 2007. Characterization of Rhizoctonia solani from potato in Great Britain. Plant Pathology 56: 286-295. DOI: 10.1111/j.13653059.2006.01545. $\mathrm{x}$

Xie S, Yu H, Li E, Wang Y, Juan Liu J, Jiang H. 2019. Identification of miRNAs involved in Bacillus velezensis FZB42-activated induced systemic resistance in maize. International Journal of Molecular Science 20: 5057. DOI:10.3390/ijms20205057

Yang J, Kloepper JW, Ryu C-M. 2009. Rhizosphere bacteria help plants tolerate abiotic stress. Trends in Plant Science 14(1): 1-4. DOI: 10.1016/j.tplants.2008.10.004

Yang S, Min F, Wang W, Wei Q, Guo M, Gao Y, Dong X, Lu D. 2017. Anastomosis group and pathogenicity of Rhizoctonia solani associated with stem canker and black scurf of potato in Heilongiiang province of China. American Journal of Potato Research 94:95104. DOI: $10.1007 / \mathrm{s} 12230-016-9535-3$

Ye M, Tang X, Yang R, Zhang H, Li F, Tao F, Li F, Wang Z. 2018. Characteristic and application of a novel species of Bacillus: Bacillus velezensis. ACS Chemical Biology 13(3):500-505. DOI: 10.1021/acschembio.7b00874

Zhang Y, Nair MG. 2010. Anthocyanin content, antioxidant, anti-inflammatory and anticancer properties of blackberry and raspberry fruits. Journal of Food Composition and Analysis. 23: 554-560. DOI: 10.1016/j.jfca.2009.08.012 


\section{Table $\mathbf{1}$ (on next page)}

The influence of $B$. velezensis strains on the growth of $R$. solani in vitro 


\begin{tabular}{|c|c|c|c|c|c|c|}
\hline \multirow{2}{*}{$\begin{array}{l}\text { Bacillus velezensis } \\
\text { strains }\end{array}$} & \multicolumn{3}{|c|}{$\begin{array}{c}\text { Colony diameter, } \mathrm{cm} \text {, } \\
\text { days }\end{array}$} & \multicolumn{3}{|c|}{$\begin{array}{c}\text { Inhibition of } R . \text { solani, \%, } \\
\text { days }\end{array}$} \\
\hline & 3 & 5 & 7 & 3 & 5 & 7 \\
\hline Control & $4.2 \mathrm{c} \pm 0,43$ & $7.9 \mathrm{~d} \pm 0,77$ & $9.0 \mathrm{~d} \pm 0,00$ & & & \\
\hline $\begin{array}{l}\text { BZR 336g } \\
10^{4} \mathrm{CFU} / \mathrm{mL}\end{array}$ & $1.8 \mathrm{ab} \pm 0,15$ & $2.1 \mathrm{ab} \pm 0,18$ & $2.4 b \pm 0,31$ & 57.1 & 73.4 & 73.3 \\
\hline $\begin{array}{l}\text { BZR 336g } \\
10^{5} \mathrm{CFU} / \mathrm{mL}\end{array}$ & $1.6 \mathrm{abc} \pm 0,11$ & $1.7 \mathrm{a} \pm 0,08$ & $1.8 \mathrm{a} \pm 0,08$ & 61.9 & 78.5 & 80.0 \\
\hline $\begin{array}{l}\text { BZR 336g } \\
10^{6} \mathrm{CFU} / \mathrm{mL}\end{array}$ & $1.4 \mathrm{c} \pm 0,09$ & $1.6 \mathrm{a} \pm 0,18$ & $1.7 \mathrm{a} \pm 0,11$ & 66.7 & 79.7 & 81.1 \\
\hline $\begin{array}{l}\text { BZR } 517 \\
10^{4} \mathrm{CFU} / \mathrm{mL}\end{array}$ & $1.9 b \pm 0,23$ & $2.6 \mathrm{c} \pm 0,58$ & $2.7 b \pm 0,67$ & 54.8 & 67.1 & 70.0 \\
\hline $\begin{array}{l}\text { BZR } 517 \\
10^{5} \mathrm{CFU} / \mathrm{mL}\end{array}$ & $1.5 \mathrm{ac} \pm 0,11$ & $1.7 \mathrm{a} \pm 0,08$ & $1.8 \mathrm{a} \pm 0,04$ & 64.3 & 78.5 & 80.0 \\
\hline $\begin{array}{l}\text { BZR } 517 \\
10^{6} \mathrm{CFU} / \mathrm{mL}\end{array}$ & $1.7 \mathrm{ab} \pm 0,30$ & $1.8 \mathrm{ab} \pm 0,05$ & $1.6 \mathrm{a} \pm 0,09$ & 59.5 & 77.2 & 82.2 \\
\hline
\end{tabular}

Table 1 The influence of $B$. velezensis strains on the growth of $R$. solani in vitro 
Table 2 (on next page)

The influence of $B$. velezensis strains on the growth of $D$. applanata in vitro 
1 Table 2 The influence of $B$. velezensis strains on the growth of $D$. applanata in vitro 2

\begin{tabular}{|c|c|c|c|c|c|c|}
\hline \multirow[t]{2}{*}{ Bacillus strains } & \multicolumn{3}{|c|}{ Colony diameter, $\mathrm{cm}$, } & \multicolumn{3}{|c|}{$\begin{array}{c}\text { Inhibition of D. applanata, } \\
\% \text {, days }\end{array}$} \\
\hline & 3 & 5 & 7 & 3 & 5 & 7 \\
\hline Control & $3.2 \mathrm{~d} \pm 0.23$ & $4.7 \mathrm{e} \pm 0.19$ & $6.4 \mathrm{~d} \pm 0.17$ & & & \\
\hline $\begin{array}{l}\text { BZR 336g } \\
10^{4} \mathrm{CFU} / \mathrm{mL}\end{array}$ & $2.4 \mathrm{bc} \pm 0.13$ & $4.1 \mathrm{~d} \pm 0.25$ & $4.6 \mathrm{c} \pm 0.11$ & 22.0 & 13.0 & 28.0 \\
\hline $\begin{array}{l}\text { BZR 336g } \\
10^{5} \mathrm{CFU} / \mathrm{mL}\end{array}$ & $2.3 \mathrm{ab} \pm 0.15$ & $3.4 \mathrm{a} \pm 0.15$ & $3.9 \mathrm{ab} \pm 0.28$ & 28.1 & 27.6 & 39.0 \\
\hline $\begin{array}{l}\text { BZR 336g } \\
10^{6} \mathrm{CFU} / \mathrm{mL}\end{array}$ & $2.5 \mathrm{c} \pm 0.19$ & $2.4 c \pm 0.12$ & $3.9 \mathrm{~b} \pm 0.25$ & 21.8 & 48.9 & 39.0 \\
\hline $\begin{array}{l}\text { BZR } 517 \\
10^{4} \mathrm{CFU} / \mathrm{mL}\end{array}$ & $2.3 \mathrm{abc} \pm 0.19$ & $3.7 b \pm 0.21$ & $5.2 c \pm 0.28$ & 28.1 & 21.3 & 18.7 \\
\hline $\begin{array}{l}\text { BZR } 517 \\
10^{5} \mathrm{CFU} / \mathrm{mL}\end{array}$ & $2.1 \mathrm{a} \pm 0.11$ & $3.5 \mathrm{ab} \pm 0.29$ & $4.6 b \pm 0.24$ & 34.3 & 25.5 & 28.1 \\
\hline $\begin{array}{l}\text { BZR } 517 \\
10^{6} \mathrm{CFU} / \mathrm{mL}\end{array}$ & $2.2 \mathrm{ab} \pm 0.09$ & $3.6 \mathrm{ab} \pm 0.16$ & $4.6 \mathrm{ab} \pm 0.31$ & 31.2 & 23.4 & 28.1 \\
\hline & $\mathrm{P}=0.36$ & $\mathrm{P}=0.35$ & $\mathrm{P}=0.11$ & & & \\
\hline
\end{tabular}

\section{Notes.}

Values followed by the same letter do not differ significantly at using Duncan,s multiple-range test 


\section{Table 3 (on next page)}

Effect of $B$. velezensis strains on disease incidence and severity caused by $R$. solani on two potato cultivars differed by disease resistance during 2015 and 2016 growing seasons in Western Siberia 
Table 3 Effect of $B$. velezensis strains on disease incidence and severity caused by $R$. solani on two potato cultivars differed by disease resistance during 2015 and 2016 growing seasons in Western Siberia

\begin{tabular}{|c|c|c|c|c|c|c|c|c|c|}
\hline \multirow{3}{*}{$\stackrel{\stackrel{\mathscr{\Xi}}{\Xi}}{\stackrel{\Xi}{\Xi}}$} & \multirow{3}{*}{ Bacillus strain } & \multirow{3}{*}{$\stackrel{\bar{\varpi}}{\check{\nu}}$} & \multicolumn{3}{|c|}{ Disease incidence, $\%$} & \multicolumn{3}{|c|}{ Disease severity, $\%$} & \multirow{3}{*}{$\begin{array}{l}\text { Disease incidence } \\
\text { on the daughter } \\
\text { tubers, } \%\end{array}$} \\
\hline & & & \multicolumn{3}{|c|}{ Weeks after planting } & \multicolumn{3}{|c|}{ Weeks after planting } & \\
\hline & & & 4 & 6 & 10 & 4 & 6 & 10 & \\
\hline \multirow{6}{*}{ 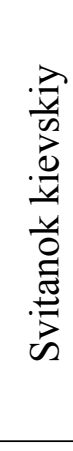 } & Control & & $21.5 \mathrm{c} \pm 1.8$ & $40.9 \mathrm{c} \pm 2.37$ & $94.4 \mathrm{c} \pm 7.27$ & $10.5 \mathrm{c} \pm 0.48$ & $17.3 \mathrm{c} \pm 1.30$ & $45.6 \mathrm{~b} \pm 5.26$ & $50.6 \mathrm{c}$ \\
\hline & BZR 336g & $\overline{\mathrm{N}}$ & $0 \mathrm{a} \pm 0$ & $15.0 \mathrm{a} \pm 1.01$ & $11.1 \mathrm{a} \pm 0.47$ & $0 \mathrm{a} \pm 0$ & $3.5 \mathrm{a} \pm 0.54$ & $3.6 \mathrm{a} \pm 0.39$ & $14.4 \mathrm{a}$ \\
\hline & BZR 517 & & $1.5 \mathrm{~b} \pm 0.05$ & $33.3 \mathrm{~b} \pm 1.97$ & $17.1 \mathrm{~b} \pm 0.55$ & $0.8 \mathrm{~b} \pm 0.04$ & $13.3 \mathrm{~b} \pm 1.08$ & $4.6 \mathrm{a} \pm 0.24$ & $25.5 b$ \\
\hline & Control & 6 & $11.2 \mathrm{c} \pm 0.15$ & $37.5 \mathrm{c} \pm 2.19$ & $83.3 \mathrm{c} \pm 2.54$ & $4.5 \mathrm{c} \pm 0.57$ & $10.0 \mathrm{a} \pm 0.73$ & $34.6 \mathrm{c} \pm 2.16$ & $86.7 \mathrm{c}$ \\
\hline & BZR 336g & ণ & $3.9 \mathrm{a} \pm 0.25$ & $20.0 \mathrm{a} \pm 1.54$ & $26.7 \mathrm{a} \pm 1.42$ & $2.1 \mathrm{a} \pm 1.64$ & $5.7 \mathrm{~b} \pm 0.26$ & $6.7 \mathrm{a} \pm 0.67$ & $5.6 \mathrm{a}$ \\
\hline & BZR 517 & & $6.3 \mathrm{~b} \pm 0.25$ & $23.3 \mathrm{~b} \pm 1.43$ & $33.3 \mathrm{~b} \pm 2.64$ & $3.0 \mathrm{a} \pm 0.40$ & $10.6 \mathrm{~b} \pm 0.89$ & $9.3 \mathrm{~b} \pm 0.59$ & $16.7 \mathrm{~b}$ \\
\hline \multirow{6}{*}{$\underset{\nu}{\stackrel{\Xi}{\Xi}}$} & Control & & $30.1 \mathrm{c} \pm 1.26$ & $82.4 c \pm 3.48$ & $83.3 \mathrm{c} \pm 3.97$ & $25.4 \mathrm{c} \pm 1.27$ & $28.2 \mathrm{c} \pm 2.16$ & $40.0 \mathrm{c} \pm 2.33$ & $40.4 c$ \\
\hline & BZR 336g & 가 & $14.1 \mathrm{a} \pm 1.38$ & $20.0 \mathrm{a} \pm 1.34$ & $26.1 \mathrm{a} \pm 1.01$ & $8.6 b \pm 0.63$ & $8.6 \mathrm{a} \pm 0.37$ & $6.1 \mathrm{a} \pm 0.42$ & $16.1 b$ \\
\hline & BZR 517 & & $18.1 \mathrm{~b} \pm 0.80$ & $29.4 \mathrm{~b} \pm 1.19$ & $61.1 \mathrm{~b} \pm 2.40$ & $7.4 a \pm 0.53$ & $14.1 \mathrm{~b} \pm 0.91$ & $23.3 b \pm 1.88$ & $4.9 \mathrm{a}$ \\
\hline & Control & & $8.3 c \pm 0.71$ & $65.9 \mathrm{c} \pm 4.81$ & $80.0 \mathrm{c} \pm 3.16$ & $20.0 c \pm 0.78$ & $23.2 \mathrm{c} \pm 0.87$ & $31.2 \mathrm{c} \pm 2.68$ & $76.7 \mathrm{c}$ \\
\hline & BZR 336g & $\overline{\mathrm{d}}$ & $4.7 \mathrm{a} \pm 0.37$ & $22.5 \mathrm{a} \pm 1.82$ & $30.0 \mathrm{a} \pm 1.95$ & $10.3 \mathrm{a} \pm 0.94$ & $6.0 \mathrm{a} \pm 0.43$ & $7.3 \mathrm{a} \pm 0.32$ & $23.3 \mathrm{a}$ \\
\hline & BZR 517 & & $7.7 b \pm 0.53$ & $34.0 \mathrm{~b} \pm 2.03$ & $56.0 \mathrm{~b} \pm 4.39$ & $14.9 b \pm 0.57$ & $11.6 \mathrm{c} \pm 1.10$ & $18.4 \mathrm{~b} \pm 1.08$ & $27.8 \mathrm{~b}$ \\
\hline
\end{tabular}

\section{Notes.}

Means followed by the same letters in the same column are not significantly different $(\mathrm{P} \leq 0.05)$ according to Duncan's multiple-range test 


\section{Table 4 (on next page)}

Effect of $B$. velezensis strains on morphometric characteristics of two potato cultivars differed by disease resistance to $R$. solani during 2015 and 2016 growing seasons in Western Siberia

Effect of $B$. velezensis strains on morphometric characteristics of two potato cultivars differed by disease resistance to $R$. solani during 2015 and 2016 growing seasons in Western Siberia 
1 Table 4 Effect of $B$. velezensis strains on morphometric characteristics of two potato cultivars 2 differed by disease resistance to $R$. solani during 2015 and 2016 growing seasons in Western 3 Siberia

\begin{tabular}{|c|c|c|c|c|c|c|c|c|}
\hline \multirow{2}{*}{ 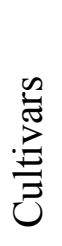 } & \multirow{2}{*}{$\begin{array}{c}\text { Bacillus } \\
\text { strain }\end{array}$} & \multirow{2}{*}{ 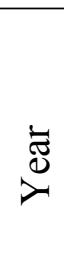 } & \multicolumn{3}{|c|}{$\begin{array}{l}\text { Plant height, } \mathrm{cm} \text {, } \\
\text { weeks after planting }\end{array}$} & \multicolumn{3}{|c|}{$\begin{array}{c}\text { The number of stems per plant, } \\
\text { weeks after planting }\end{array}$} \\
\hline & & & 4 & 6 & 10 & 4 & 6 & 10 \\
\hline \multirow{6}{*}{ 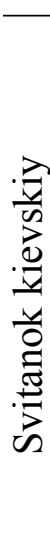 } & Control & \multirow{3}{*}{$\stackrel{n}{\frac{n}{2}}$} & $11.6 \mathrm{a} \pm 0.7$ & $22.4 \mathrm{a} \pm 1.4$ & $31.1 \mathrm{~b} \pm 1.8$ & $2.1 \mathrm{a} \pm 0.2$ & $4.4 \mathrm{a} \pm 0.3$ & $4.6 b \pm 0.4$ \\
\hline & BZR 336g & & $11.8 \mathrm{a} \pm 0.7$ & $26.7 b \pm 1.7$ & $40.1 \mathrm{a} \pm 1.7$ & $5.1 \mathrm{c} \pm 0.5$ & $7.0 \mathrm{c} \pm 0.4$ & $8.0 \mathrm{a} \pm 0.4$ \\
\hline & BZR 517 & & $12.6 \mathrm{a} \pm 0.7$ & $24.7 \mathrm{c} \pm 1.4$ & $38.5 \mathrm{a} \pm 2.0$ & $3.7 \mathrm{~b} \pm 0.4$ & $6.0 \mathrm{~b} \pm 0.4$ & $7.1 \mathrm{a} \pm 0.5$ \\
\hline & Control & \multirow{3}{*}{ 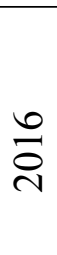 } & $24.0 \mathrm{~b} \pm 1.9$ & $31.2 \mathrm{a} \pm 2.1$ & $38.2 \mathrm{a} \pm 1.8$ & $3.6 \mathrm{a} \pm 0.4$ & $4.4 \mathrm{a} \pm 0.2$ & $5.0 \mathrm{a} \pm 0.6$ \\
\hline & BZR 336g & & $30.0 \mathrm{a} \pm 2.1$ & $37.4 b \pm 2.1$ & $41.2 b \pm 2.7$ & $7.0 \mathrm{c} \pm 0.4$ & $7.0 \mathrm{c} \pm 0.6$ & $8.0 \mathrm{c} \pm 0.5$ \\
\hline & BZR 517 & & $28.0 \mathrm{a} \pm 1.3$ & $34.6 a b \pm 1.9$ & $39.0 \mathrm{ab} \pm 1.9$ & $5.0 b \pm 0.4$ & $6.0 \mathrm{~b} \pm 0.5$ & $6.0 \mathrm{~b} \pm 0.4$ \\
\hline \multirow{6}{*}{$\underset{\Xi}{\Xi}$} & Control & \multirow{3}{*}{$\frac{n}{0}$} & $11.6 \mathrm{a} \pm 1.0$ & $31.0 \mathrm{a} \pm 1.5$ & $31.2 \mathrm{a} \pm 1.4$ & $3.0 \mathrm{a} \pm 0.2$ & $3.4 b \pm 0.4$ & $3.4 b \pm 0.2$ \\
\hline & BZR 336g & & $15.9 \mathrm{~b} \pm 0.8$ & $33.1 \mathrm{~b} \pm 1.4$ & $43.2 b \pm 1.4$ & $4.0 \mathrm{c} \pm 0.2$ & $4.6 \mathrm{a} \pm 0.3$ & $6.0 \mathrm{a} \pm 0.6$ \\
\hline & BZR 517 & & $12.6 \mathrm{a} \pm 0.9$ & $30.2 \mathrm{a} \pm 2.3$ & $33.9 \mathrm{a} \pm 1.5$ & $3.5 b \pm 0.3$ & $4.4 \mathrm{a} \pm 0.3$ & $5.4 \mathrm{a} \pm 0.5$ \\
\hline & Control & \multirow{3}{*}{ 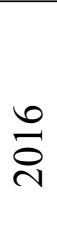 } & $19.0 \mathrm{a} \pm 1.2$ & $27.2 b \pm 1.6$ & $31.0 \mathrm{a} \pm 1.8$ & $2.4 \mathrm{a} \pm 0.2$ & $3.4 \mathrm{a} \pm 0.4$ & $4.0 \mathrm{a} \pm 0.3$ \\
\hline & BZR 336g & & $28.0 \mathrm{c} \pm 1.8$ & $34.0 \mathrm{a} \pm 1.7$ & $41.4 \mathrm{~b} \pm 2.4$ & $4.6 \mathrm{c} \pm 0.3$ & $5.0 \mathrm{c} \pm 0.4$ & $6.0 \mathrm{~b} \pm 0.4$ \\
\hline & BZR 517 & & $22.0 b \pm 1.7$ & $32.2 \mathrm{a} \pm 1.3$ & $34.8 \mathrm{a} \pm 1.7$ & $3.8 \mathrm{~b} \pm 0.4$ & $4.0 \mathrm{~b} \pm 0.3$ & $4.4 \mathrm{a} \pm 0.3$ \\
\hline
\end{tabular}

\section{Notes.}

Means followed by the same letters in the same column are not significantly different $(\mathrm{P} \leq 0.05)$ according to Duncan's multiple-range test

4

5 


\section{Table 5 (on next page)}

Effect of $B$. velezensis strains on the biomass distribution of daughter tubers of two potato cultivars differed by disease resistance to $R$. solani and total yield during 2015 and 2016 growing seasons in Western Siberia 
1 Table 5 Effect of $B$. velezensis strains on the biomass distribution of daughter tubers and total yield of two potato cultivars during

\begin{tabular}{|c|c|c|c|c|c|c|c|c|c|}
\hline \multirow{3}{*}{ 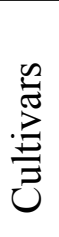 } & \multirow{3}{*}{$\begin{array}{c}\text { Bacillus } \\
\text { strain }\end{array}$} & \multicolumn{6}{|c|}{ Biomass distribution by fractions, $\%$} & \multicolumn{2}{|c|}{ Yield, $\mathrm{t} \mathrm{ha}^{-1}$} \\
\hline & & \multicolumn{3}{|c|}{2015} & \multicolumn{3}{|c|}{2016} & \multirow[b]{2}{*}{2015} & \multirow[b]{2}{*}{2016} \\
\hline & & small & medium & large & small & medium & large & & \\
\hline \multirow{3}{*}{ 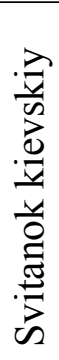 } & Control & $16.6 \mathrm{c} \pm 0.7$ & $64.1 b \pm 2.5$ & $19.3 b \pm 0.6$ & $16.9 \mathrm{c} \pm 0.7$ & $58.3 \mathrm{~b} \pm 1.9$ & $24.8 \mathrm{~b} \pm 1.6$ & $20.3 \mathrm{a} \pm 1,2$ & $11.6 \mathrm{c} \pm 0,9$ \\
\hline & BZR 336g & $8.4 \mathrm{~b} \pm 0.4$ & $59.1 \mathrm{a} \pm 1.3$ & $32.5 \mathrm{c} \pm 1.7$ & $4.6 \mathrm{a} \pm 0.2$ & $52.8 \mathrm{a} \pm 2.5$ & $40.0 \mathrm{c} \pm 1.8$ & $28.7 \mathrm{~d} \pm 0,3$ & $18.9 \mathrm{a} \pm 1,1$ \\
\hline & BZR 517 & $11.8 \mathrm{a} \pm 0.8$ & $75.3 \mathrm{a} \pm 2.4$ & $12.9 \mathrm{a} \pm 0.7$ & $7.2 \mathrm{~b} \pm 0.4$ & $71.7 \mathrm{c} \pm 2.5$ & $21.1 \mathrm{a} \pm 1.3$ & $22.0 \mathrm{~b} \pm 0,6$ & $16.5 b \pm 0,7$ \\
\hline \multirow{3}{*}{$\underset{\Xi}{\Xi}$} & Control & $13.1 \mathrm{c} \pm 0.9$ & $63.8 \mathrm{a} \pm 4.3$ & $23.1 \mathrm{a} \pm 1.5$ & $11.4 \mathrm{c} \pm 1.0$ & $67.8 \mathrm{a} \pm 5.4$ & $20.8 b \pm 1.3$ & $21.0 \mathrm{ab} \pm 0,7$ & $15.5 b \pm 0,3$ \\
\hline & BZR $336 g$ & $3.8 \mathrm{a} \pm 0.2$ & $54.2 \mathrm{~b} \pm 2.3$ & $42.0 \mathrm{c} \pm 2.3$ & $3.0 \mathrm{a} \pm 0.4$ & $66.7 \mathrm{a} \pm 3.1$ & $30.3 \mathrm{a} \pm 1.8$ & $25.7 \mathrm{c} \pm 1,6$ & $19.7 \mathrm{a} \pm 0,7$ \\
\hline & BZR 517 & $6.0 \mathrm{~b} \pm 0.4$ & $65.9 \mathrm{a} \pm 4.5$ & $28.1 \mathrm{~b} \pm 1.2$ & $6.3 b \pm 0.6$ & $64.8 \mathrm{a} \pm 3.6$ & $28.9 \mathrm{a} \pm 1.4$ & $24.6 \mathrm{c} \pm 1,3$ & $19.6 \mathrm{a} \pm 1,1$ \\
\hline
\end{tabular}

\section{Notes.}

Means followed by the same letters in the same column are not significantly different $(\mathrm{P} \leq 0.05)$ according to Duncan's multiple-range test

2015 and 2016 growing seasons in Western Siberia. 


\section{Table 6(on next page)}

Effect of $B$. velezensis strains on disease incidence and severity caused by $D$. applanata on two raspberry cultivars differed by disease resistance and total yield during 2015 and 2016 growing seasons in Western Siberia 
1 Table 6 Effect of $B$. velezensis strains on disease incidence and severity caused by D. applanata 2 and total yield of two raspberry cultivars during 2015 and 2016 growing seasons in Western Siberia

\begin{tabular}{|c|c|c|c|c|c|c|c|}
\hline \multirow{2}{*}{$\frac{\dot{\Xi}}{\stackrel{\Xi}{\Xi}}$} & \multirow[t]{2}{*}{$\begin{array}{l}\text { Bacillus } \\
\text { strain }\end{array}$} & \multirow{2}{*}{$\ddot{\nexists ̈}$} & \multicolumn{2}{|c|}{$\begin{array}{c}\text { Disease incidence, \% } \\
\text { weeks }\end{array}$} & \multicolumn{2}{|c|}{$\begin{array}{c}\text { Disease severity, \% } \\
\text { weeks }\end{array}$} & \multirow[t]{2}{*}{ Yield, $\mathrm{t} \mathrm{ha}^{-1}$} \\
\hline & & & 4 & 12 & 4 & 12 & \\
\hline \multirow{6}{*}{ 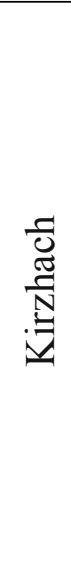 } & Control & & $32.5 \mathrm{c} \pm 5.0$ & $70.0 \mathrm{~d} \pm 8.2$ & $8.1 b \pm 1.3$ & $20.5 b \pm 3.2$ & $3.30 \mathrm{~b} \pm 0.09$ \\
\hline & BZR 336g & $\frac{n}{\stackrel{n}{c}}$ & $15.0 \mathrm{~b} \pm 5.8$ & $40.0 \mathrm{c} \pm 8.2$ & $3.8 \mathrm{a} \pm 1.4$ & $10.0 \mathrm{a} \pm 2.0$ & $3.50 \mathrm{a} \pm 0.02$ \\
\hline & BZR 517 & & $10.0 \mathrm{ab} \pm 0$ & $37.5 b c \pm 5.0$ & $2.5 \mathrm{a} \pm 0.0$ & $9.4 a \pm 1.3$ & $3.52 \mathrm{a} \pm 0.01$ \\
\hline & Control & & $42.5 b \pm 12.6$ & $52.5 \mathrm{c} \pm 5.0$ & $10.6 \mathrm{~b} \pm 0.6$ & $19.4 b \pm 3.8$ & $1.32 \mathrm{c} \pm 0.03$ \\
\hline & BZR 336g & $\stackrel{0}{\underset{\sim}{0}}$ & $12.5 \mathrm{a} \pm 5.0$ & $42.5 \mathrm{ac} \pm 9.6$ & $3.1 \mathrm{a} \pm 0.7$ & $11.3 \mathrm{a} \pm 1.2$ & $1.37 \mathrm{a} \pm 0.02$ \\
\hline & BZR 517 & & $12.5 \mathrm{a} \pm 5.0$ & $37.1 \mathrm{a} \pm 8.8$ & $3.1 \mathrm{a} \pm 0.7$ & $9.3 \mathrm{a} \pm 1.6$ & $1.41 \mathrm{~b} \pm 0.01$ \\
\hline \multirow{6}{*}{$\begin{array}{l}\frac{y}{3} \\
\frac{0}{0} \\
0 \\
\frac{y}{0} \\
0 \\
1\end{array}$} & Control & & $9.2 \mathrm{ab} \pm 0.7$ & $30.0 \mathrm{~b} \pm 0.0$ & $2.3 \mathrm{a} \pm 0.5$ & $7.5 b \pm 2.2$ & $3.61 \mathrm{a} \pm 0.01$ \\
\hline & BZR 336g & $\frac{n}{0}$ & $3.8 \mathrm{a} \pm 4.4$ & $15.9 \mathrm{a} \pm 4.1$ & $1.0 \mathrm{a} \pm 1.2$ & $4.0 \mathrm{a} \pm 0.5$ & $3.62 \mathrm{a} \pm 0.00$ \\
\hline & BZR 517 & & $4.6 \mathrm{a} \pm 3.5$ & $12.1 \mathrm{a} \pm 4.3$ & $1.2 \mathrm{a} \pm 1.4$ & $3.0 \mathrm{a} \pm 0.2$ & $3.61 \mathrm{a} \pm 0.00$ \\
\hline & Control & & $15.0 \mathrm{a} \pm 12.9$ & $32.5 \mathrm{a} \pm 9.6$ & $3.8 \mathrm{a} \pm 3.2$ & $8.1 b \pm 2.4$ & $2.59 \mathrm{a} \pm 0.02$ \\
\hline & BZR 336g & $\stackrel{0}{\stackrel{0}{0}}$ & $7.5 \mathrm{a} \pm 5.0$ & $16.3 b \pm 4.2$ & $1.9 \mathrm{a} \pm 2.4$ & $4.1 \mathrm{a} \pm 1.1$ & $2.60 \mathrm{ab} \pm 0.01$ \\
\hline & BZR 517 & & $6.3 \mathrm{a} \pm 4.4$ & $15.0 \mathrm{~b} \pm 5.8$ & $1.6 \mathrm{a} \pm 1.2$ & $3.8 \mathrm{a} \pm 1.4$ & $2.60 \mathrm{ab} \pm 0.01$ \\
\hline
\end{tabular}

\section{Notes.}

Means followed by the same letters in the same column are not significantly different $(\mathrm{P} \leq 0.05)$ according to Duncan,s multiple-range test 


\section{Figure 1}

A, B - antifungal activity of $B$. velezensis against $R$ solani in vitro; $C, D$ - antifungal activity of $B$. velezensis against $D$. applanata in vitroa - $104 \mathrm{CFU} / \mathrm{mL}, \mathrm{b}-105 \mathrm{CFU} / \mathrm{mL}, \mathrm{C}$ $106 \mathrm{CFU} / \mathrm{mL}, \mathrm{d}$ - control

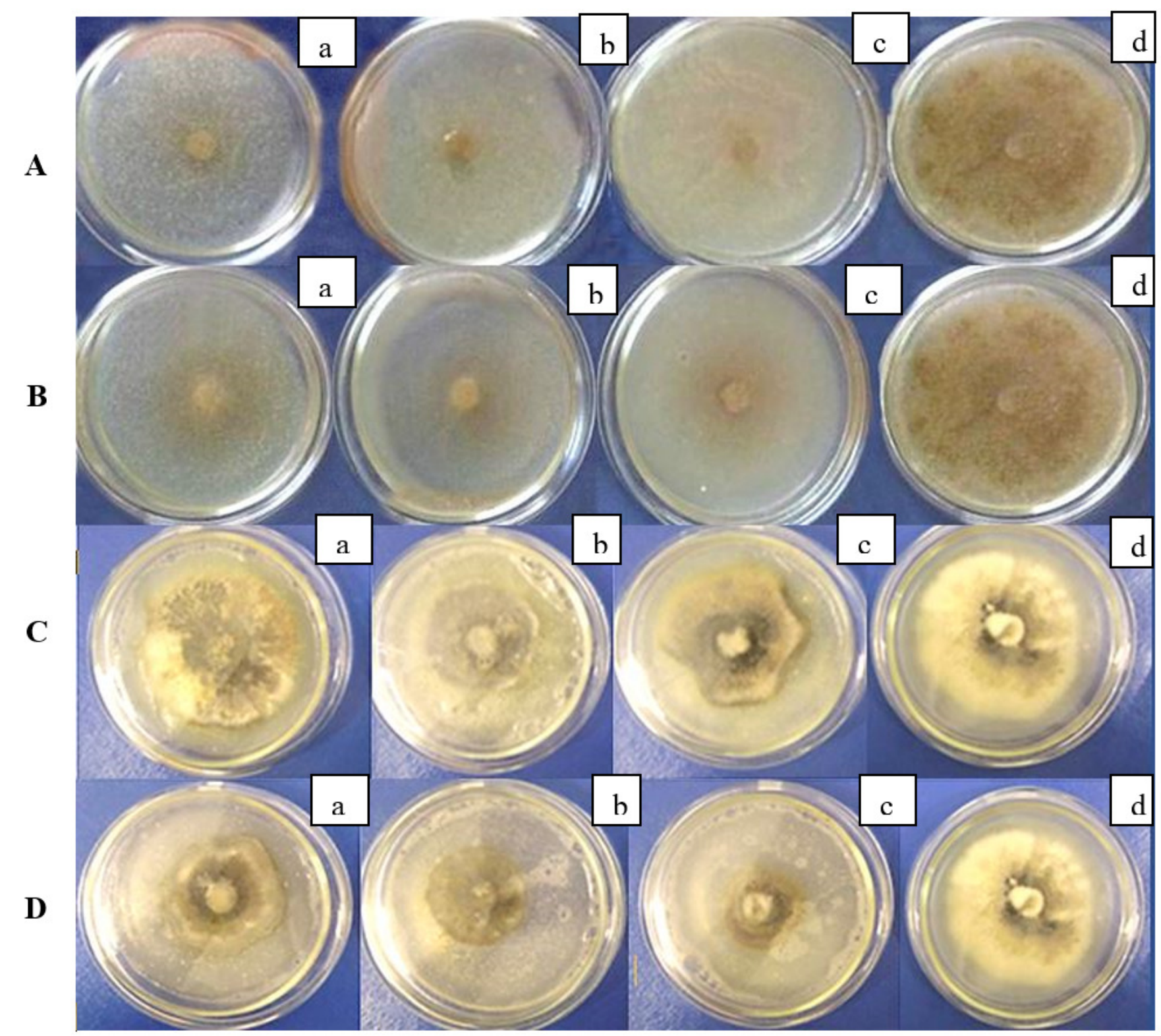

